\title{
The Absurd Consciousness of Those Lying in a Health Care System About to Collapse
}

\author{
Kendy Madero Zambrano ${ }^{1}$, Shirley Fernández Aragón ${ }^{2}$, Moraima Del toro Rubio ${ }^{2}$, Zorayda Barrios Puerta ${ }^{3}$, \\ Yolima Manrique Anay ${ }^{2} \&$ Sandra L Vallejo Arias ${ }^{1}$ \\ ${ }^{1}$ Faculty of Health Sciences, University Corporation Rafael Núñez, Cartagena de Indias, Colombia \\ ${ }^{2}$ Faculty of Health Sciences, University Corporation Rafael Núñez, University of Cartagena, Cartagena de Indias, \\ Colombia \\ ${ }^{3}$ Faculty of Health Sciences, University Corporation Rafael Núñez, University of Sinú, Cartagena de Indias, \\ Colombia \\ Correspondence: Kendy Madero Zambrano, Faculty of Health Sciences, University Corporation Rafael Núñez, \\ Cartagena de Indias, Colombia. Tel: 30-14-625-271. E-mail: kendy.madero@curnvirtual.edu.co
}

Received: September 27, 2018 Accepted: November 13, 2018 Online Published: November 15, 2018

doi:10.5539/gjhs.v10n12p116 URL: https://doi.org/10.5539/gjhs.v10n12p116

\begin{abstract}
Introduction: The healthcare sector crisis is a reality affecting countries all over the world. In order to mitigate it, different cost-effective measures, such as promotion of health and disease prevention, have been implemented. However, several variables may limit these measures, among which are patients' responsibilities. Objectives: In this study patient behavior (disease knowledge and self-care practices) as a determinant factors in the healthcare system crisis was analyzed in a group of hypertensive patients.
\end{abstract}

Methods: This was a descriptive correlational cross-sectional study in which 185 patients diagnosed with high blood pressure attending the high blood pressure program at three different primary health care locations in Cartagena, Colombia 2017. A questionnaire, structured into three components: 1) sociodemographic characteristics, 2) disease knowledge, and 3) self-care practices and lifestyle, was administered to participating individuals. The Analysis of the information was made in SPSS version 22.

Results: The average hypertensive disease knowledge was high (60.5\%). Self-care practices were rated as mediocre $(73.5 \%)$ or poor $(24.3 \%)$. A significant correlation establishing that with increased level of disease knowledge, self-care practices improve by $11.5 \%(\mathrm{p}<0.05)$.

Conclusion: Patient behavior constitutes a determinant factor in the health care system crisis, since although hypertensive patients possess good disease knowledge, they do not put it into practice, constituting an absurd attitude taking into account that it's related to their wellbeing, and it turns into an attack on a health care system that is about to collapse.

Keywords: consciousness, healthcare systems, hypertension, medical economics, outpatient care, DeCS

\section{Introduction}

Worldwide, health has traditionally been a hot topic for the political and economic sectors. Because of its high social content, discussions on health issues are of constant interest. Indeed, advocating for the protection of life without exception, distinction, or discrimination, is challenging work that is based on a fully structured model whose goal is to guarantee health as a fundamental social right (OMS, 2015; Semplicl, 2011), and that -without a doubt- requires large-scale investments. However, over the past years we have witnessed the crisis faced by the healthcare sector, attributed to problematic situations that push the system to its limit (Ruiz, 2011; Ongaro, Ferre, $\&$ Fatore, 2015). One of such situations is the crisis of the economic sector, a reality affecting countries all over the world and that is of great relevance as it may significantly impact poverty rates (Hadad \& Valdés 2010; Ifanti, Argyriou, Kalofonou, \& Kalofonos, 2013; Correia, Dussault, \& Pontes 2015).

To this end, recent estimates by the World Bank show a discouraging scenario for the healthcare sector, since despite the achieved progress on reducing poverty worldwide, extreme poverty rates remain at "unacceptably high" levels, leading to inequality in health care in which "poor people face higher risks of malnutrition and death in 


\section{childhood and are at lower odds of receiving key health care interventions" Mundial Banco (2016).}

Similarly, additional difficulties exacerbating this context are evasion and abrogation, which are factors that unbalance the system's sustainability when key players, in one way or another, avoid their responsibility. Likewise, in the absence of an integrated information system it is nearly impossible to detect these and other leaks. Unmistakably, this situation is a consequence of the lack of control of the system leading the processes, which leaves an omnipresent gap to be easily accessible by another great enemy of the health care system: corruption. As a consequence of budget deviation, low investment, and delays in flow of resources favored by corruption, the system suffers irreversible damage evidenced by depletion of resources, decline in health care, and increased health care costs, poor health (Yepes \& Sánchez, 2008; Roca, 2017; Chattopdhyay, 2013).

However, experts have declared that in order to mitigate the effects of the financial crisis, the current approaches need to be reconsidered and new strategies guaranteeing the system's sustainability must be implemented, being primary health care (PHC) and its focus on health promotion and disease prevention the tool with the best access and lowest cost. Therefore, PHC is a cost-effective strategy that by connecting the individual to its environment aims to impact their living conditions and way of living (Catford \& Nutbeam 1984; Urbanos, 2010), through the adoption of self-controlled behaviors, thus providing a healthier future (Guibert, 2002).

Nonetheless, regardless of the efforts made around this strategy, significant changes remain to be observed. Some experts associate this to several types of barriers including "political (legislative reforms that reduce population rights, budget cuts, and change direction of policies, such as the labor reform), organizational (lack of management professionalization, cuts in schedule and services), professional (discouragement), and those related to the population (increased of vulnerable population, priority changes, medicalization)" Márquez, Villegas, Soler, and Martinez (2014). Yet, despite this, promotion of health and prevention of disease is still the strategy that represents great opportunities for the healthcare sector, but must be optimized in order to provide more efficient primary health care, with the ability, safety, and motivation to work with the community (E, Cabeza, March, C, Cabeza \& Segura, 2016; Sørensen \& Brand, 2011).

However, this context reveals the role of a factor that has been underestimated for years: consciousness, defined as "the knowledge of good and evil that allows a person to morally judge reality and actions, especially their own", and whose absence is perhaps one of the most disturbing factors of all (Diccionario de la lengua española, 1992). Unfortunately, we find ourselves in a society whose lack of consciousness grows every day; individuals are less responsible for their own health, patients being indifferent to their state of health, and patients making irresponsible decisions. This is paradoxical considering that this is related to their wellbeing, and instead become a burden thus contributing to a health care system on the border of collapse. On this matter, Ahola proposes that patient responsibility may be diminished on account of the lack of control of the healthcare system, arguing that while this is an individual compromise, there are additional factors of cultural, social, and socioeconomic nature that need to be taken into consideration (Ahola, 2015).

Therefore, there is a need to document if patients take responsibility for their own health. In this study, in a group of patients with high blood pressure, we analyzed the association between patients' disease knowledge and health self-care practices with the goal of demonstrating how responsible patients were in taking care of their disease, and how this can be a determinant factor in the health care system crisis.

High blood pressure is the most frequent non-communicable disease in adults, and its high rates make it a relevant public health issue. Furthermore, high blood pressure is associated with comorbidities that lead to increased mortality, disability, and poor quality of life. While this disease is currently easily diagnosed and treated, its increased prevalence and incidence -especially in younger populations- have raised concerns among the healthcare community (Gonzalez, Rodriguez, Castellano, \& Pérez, 2014; Marín et al., 2012).

Importantly, among risk factors for high blood pressure are intrinsic individual factors such as unhealthy diet and habits such as smoking, physical inactivity, overweight, and obesity, as well as genetic factors (Solano, Tamay, Quizhpe, \& Villamar, 2017). Therefore, lifestyle modifications to implement healthier habits are required for prevention and/or control of high blood pressure (Mazón, 2012). Similarly, performing proper self-care practices leads to a reduced risk of cardiovascular events (Blanco, 2017). Altogether, these are matters in which patients take responsibility for their own health; thus their behavior plays an essential role in maintaining and improving their quality of life and of the healthcare system.

Regarding the cost inflicted on the healthcare system due to management of patients with high blood pressure, a study in Peru estimated that, compared to the limited health care system budget, it is significantly elevated (Chávez, Villafuente, \& Legua, 2008) since on average a hypertensive patient costs twice as much as a patient with normal 
blood pressure (Saenz \& Barceló, 2012). In relation to direct and indirect costs associated to complications of high blood pressure, the World Health Organization estimates that cardiovascular disease represents for the US, in 2010 , around US\$ 863.000 millions, and for 2030 projected costs are to be US\$1,04 billons. Furthermore, the WHO states that it is one of the causes of poverty that hinder economic development around the world, representing a substantial obstacle to achieve millennium development goals and their fight against poverty (Bloom et al., 2012; Gómez, 2011).

\section{Materials and Methods}

This was a descriptive correlational cross-sectional study of quantitative nature, being the correlational aspect is the main focus of this study since the goal was to establish the association between two or more variables (Arias, 2012), which in this case were the knowledge and health self-care practices of a group of hypertensive patients. Therefore providing evidence on how involved these patients are in taking responsibility of their disease.

According to statistical sample size calculations, based on a confidence level of $95 \%$ and a margin of error of 5\%, 185 individuals were determined who met the following inclusion criteria: 1) patient registered in the hypertensive club, 2) age $>18$ years, 3) habitual resident of the place where the study was conducted. This sample was significant because it represents the total population that attends the local hypertensive program.

Two questionnaires were used in this study: the "Knowledge about hypertension" questionnaire, which is a structured questionnaire previously validated by Reventos (Reventos et al., 2013) that takes into account 6 dimensions: hypertension, risk factors for hypertension, diet, medication, lifestyle modifications, and perception of disease. A second questionnaire entitled "Lifestyle of the patient with high blood pressure" (Arrioja, 2011), which is distributed in 6 sub-scales: health responsibility, exercise, nutrition, stress management, no tobacco use, and no alcohol consumption.

Prior to questionnaire administration, all participating individuals provided signed informed consent. According to Resolution 8430 of 1993(Ministerio de salud de la República de Colombia, 1993), and since this study's goal was to establish statistical significance, it is classified into the no-risk category.

The analysis of the information was univariated, using frecuency and percentages in SPSS software (Statistical package for the social Sciences) version 22. Univariate analysis was carried out using the measurement of frequency and the statistical association between the factors using the bivariate analysis. By means Chi Square and the value of its probability, accepting as statistically significant with $\mathrm{p}<0.05$.

\section{Results}

\subsection{Sociodemographic Characteristics}

According to Sociodemographic characteristics, predominance of female hypertensive patients was observed, representing $64.3 \%$ of the respondents. Regarding age, relatively older adults ( $>50$ years old) had the highest representation in the sample, being $36.2 \%$ those between 50 and 59 years of age, and $34.1 \%$ those over 60 years old The educational level was low, since the majority of participants completed up to elementary $(47.6 \%)$, or high school (37.3\%) levels, and only a few achieved technical or technological studies $(8.6 \%)$, undergraduate $(0.5 \%)$, or graduate $(0.5 \%)$ degrees, while no schooling was reported by $5.4 \%$.

Regarding socioeconomic level, it was evident that most participants were classified in the lowest level that is level 1 , which is consistent with the known lack of resources of the population residing in the study areas.

\subsection{Disease Knowledge}

Our results show that the majority of hypertensive patients in all three communities have high knowledge of their disease $(60.5 \%)$. While patients exhibiting poor disease knowledge were few $(2.7 \%)$, a noteworthy proportion of patients were categorized as having mediocre disease knowledge (36.8\%).

\subsection{Results by Questionnaire Dimensions}

\subsubsection{Generalities on Hypertension}

In this regard, the majority of surveyed patients (91.4\%) correctly identified hypertension as a lifelong disease, and while most of them (84.9\%) acknowledge that the meaning of hypertension has been explained to them, they lack clarity regarding the values starting at which a person is considered have high blood pressure (28.6\%).

\subsubsection{Diet}

All participating communities exhibited a high proportion of patients correctly answering diet-related questions. Specifically, they are aware of the need to reduce sodium intake ( $88.6 \%)$, of the relevance of diet for hypertensive 
patients, and that a low-fat diet rich in fruits and vegetable is important to reduce blood pressure (84.3\%).

\subsubsection{Risk Factors for Hypertension}

The majority of the study population knows that a hypertensive patient that smokes cigarettes has an increased risk of suffering from heart disease (93.0\%), and that if in addition, suffering from diabetes increases risk of cardiac disease (89.7\%); collectively, a hypertensive patient with high cholesterol has an increased risk of heart disease $(85.4 \%)$, likewise, an obese hypertensive patient faces a similar risk (89.4\%).

\subsubsection{Medication}

A certain level of ignorance was identified in several of the questions, since the proportion of knowledge was not as high as in previous dimensions. The fact that only $29.2 \%$ of patients knew that medication on its own does not control hypertension stood out. In addition, $57.8 \%$ knew that doses of medication could not (and should not) be increased or reduced if blood pressure was going up or down. Finally, only $63.8 \%$ knew that treatment should not be suspended when blood pressure control was achieved.

\subsubsection{Lifestyle Modifications}

First, it is worth pointing out that only a small percentage of participants (14.6\%) correctly identified that in obese patients weight loss is associated with lowering of blood pressure. On the other hand, a high proportion of patients correctly responded that leading a tranquil lifestyle favors control of hypertension (90.3\%), and that walking 30 minutes to 1 hour every day reduces the risk of heart disease (87\%).

\subsubsection{Risk of Hypertension}

According to our results, $87 \%$ of participating individuals were aware that this condition may lead to heart disease, and $74.1 \%$ of them recognized that it may also lead to renal disease. To a lesser extent in each community, $54.6 \%$, $54.1 \%$, and $49.2 \%$ were aware that this chronic disease is associated with visual impairment, brain disease, and arthrosis, respectively.

\subsection{Self-Care Practices for Disease Management}

Regarding disease care practices, the majority of hypertensive patients (73.5\%) reported performing acceptable practices of hypertension care, followed by $24.3 \%$ that reported poor care practices, and only $2.2 \%$ reported good care practices. When separated by community, we observed that in all three of them the majority of patients reported acceptable care practices being $74.3 \%$ in $A, 72.7 \%$ in $B$, and $73.5 \%$ in $C$.

\subsection{Results by Questionnaire Dimensions}

\subsubsection{Exercise}

Regarding exercise, the results were unfavorable since the majority of hypertensive patients did not exercise (62.2\%), and only $37.3 \%$ were categorized as exercising regularly. Furthermore, analysis of disaggregated items of this dimension, considering a 1 to 4 scale, showed clearly unfavorable results since the general average was 2 points, and it was evidenced that they seldom evaluate their pulse during exercise (average 1.65 of 4 points), or participate in supervised physical activity programs for weight loss and blood pressure control (average 1.99).

In contrast, the highest averages -although not the best overall- were achieved for exercising to stretch muscles at least 3 times per week, as well as to do recreational activities such as walking, swimming, playing soccer, biking, in order to loose weight and to control blood pressure (each with an average of 2.65 points).

\subsubsection{Stress Management}

Evaluation of self-care practices related to stress management showed a predominance of those performing self-care practices at an acceptable level (59.5\%), followed by poor self-care practices performed by $39.5 \%$. Data disaggregation showed that on average ( 2.45 points) patients were aware of the sources of stress in their lives, and took time during the day to relax (average 2.43 points). In contrast, the lowest scores were observed when asked about how to use specific methods to manage stress (average of 1.77 points), and regarding focusing on positive thoughts before falling asleep (average of 2.09 points).

\subsubsection{Nutritional Habits}

This practice was mostly classified as being performed at an acceptable level $(61.1 \%)$, while poor practices were identified in $28.1 \%$ of participants, and good practices were only reported in $10.8 \%$ of patients. The best practices corresponded to having breakfast when getting up in the morning (average of 2.88 points), eating three meals per day (average of 2.77 points), and including high-fiber foods (whole grains, raw fruits and vegetables) in their diet in order to loose weight and control blood pressure (average of 2.46 points). On the contrary, practices with the 
lowest scores were those including actions such as choosing foods without artificial or chemical food preservatives (average of 2.26 points), reading nutrinional labels for packaged foods and choosing those low on cholesterol and sodium (average of 2.06 points).

\subsubsection{Health Responsibility}

In this study, participating subjects exhibited acceptable health responsibility practices (67\%), both generally and by communities. Regarding health responsibility of hypertensive patients, remarkable differences were observed between practices. On one hand, the best considerations were achieved in practices such as participation in educational programs on personal health care (average 2.72 points), communicating any unusual symptoms of hypertension to the doctor (average 2.70 points), and attending educational programs on control of your blood pressure (average 2.65 points). On the other hand, less favorable opinions were observed in relation to practices such as avoiding alcohol consumption during social gatherings without feeling forced because it is known that it benefits your blood pressure (average 2.042 points), and evaluation of blood pressure and knowing the result (average 1.88 points).

\subsubsection{Alcohol Intake}

Analysis of alcohol intake-related practices in this population revealed a critical point, since the majority reported acceptable practices $(62.2 \%)$, followed by poor practices $(35.7 \%$ ), and a scarce $2.2 \%$ reported good practices. Disaggregated data showed that hypertensive patients consciously try to avoid alcohol intake in order to control their blood pressure (average 2.60 points). In contrast, our results indicate scarce disease literacy, as the lowest scores were obtained for reading journals or brochures providing information about alcohol-induced organ damage (average of 2.04 points).

\subsubsection{Use of Tobacco}

Our data suggest that, regarding use of tobacco, practices were reported as acceptable (67\%), and poor (31.9\%). It was noteworthy that specific practices exhibited very low average scores (scale 1 to 4 ), particularly relating to reading journals or brochures providing information on health damage induced by use of tobacco (average 2.04 points), seating in non-smoking areas in enclosed places (average 2.16 points), and using strategies to avoid using tobacco products (average 2.52 points).

\subsection{Correlation Between Sociodemographic Characteristics, Disease Knowledge And Self-Care Practices}

Regarding the correlation between sociodemographic characteristics, disease knowledge, and self-care practices among hypertensive patients, our data indicate that among the sociodemographic variables correlating with self-care practices is education. Moreover, with each educational level that the patient ascends, the greater the positive effect on self-care practices. Specifically, we found that compared with patients with no schooling, self-care practices improve by $54 \%$ in patients with elementary education, by $72.6 \%$ in in those with high school education, by $90.6 \%$ in those with technical or technological degree, and by $94.4 \%$ in those with college degree. All of the correlation coefficients were statistically significant $(\mathrm{p}<0.05)$ (Table 1$)$. 
Table 1. Logarithmic linear regression model between sociodemographic characteristics and disease knowledge (independent variables), on self-care practices on hypertensive patients (dependent variable)

\begin{tabular}{|c|c|c|c|c|c|c|c|c|c|}
\hline \multirow[b]{2}{*}{ Variables } & \multirow[b]{2}{*}{ Categories } & \multicolumn{2}{|l|}{ General } & \multicolumn{2}{|l|}{ Canapote } & \multicolumn{2}{|c|}{ San Francisco } & \multicolumn{2}{|c|}{ Tierra Bomba } \\
\hline & & Coefficient & $\begin{array}{l}\mathrm{p} \\
\text { value }\end{array}$ & Coefficient & $\begin{array}{l}\mathrm{p} \\
\text { value }\end{array}$ & Coefficient & $\begin{array}{l}\mathrm{p} \\
\text { value }\end{array}$ & Coefficient & $\begin{array}{l}\mathrm{p} \\
\text { value }\end{array}$ \\
\hline \multirow{2}{*}{ Gender } & Male & - & - & - & - & - & - & - & - \\
\hline & Female & $15,2 \%$ & 0,076 & $-10,5 \%$ & 0,526 & $25,1 \%$ & 0,039 & $21,9 \%$ & 0,244 \\
\hline \multicolumn{10}{|l|}{ Age (years) } \\
\hline \multirow{6}{*}{ Education } & No schooling & - & - & - & - & - & - & - & - \\
\hline & Primary & $54,0 \%$ & 0,000 & $95,8 \%$ & 0,002 & $22,8 \%$ & 0,258 & $125,2 \%$ & 0,019 \\
\hline & High School & $72,6 \%$ & 0,000 & $115,4 \%$ & 0,000 & $47,6 \%$ & 0,018 & $130,5 \%$ & 0,009 \\
\hline & Technical/technological & $104,6 \%$ & 0,000 & $149,7 \%$ & 0,000 & $97,2 \%$ & 0,000 & $92,7 \%$ & 0,121 \\
\hline & Undergraduate & $144,4 \%$ & 0,006 & & & - & - & $181,8 \%$ & 0,008 \\
\hline & Graduate & $51,6 \%$ & 0,430 & $73,4 \%$ & 0,341 & - & - & - & - \\
\hline \multirow{3}{*}{$\begin{array}{l}\text { Monthly } \\
\text { income }\end{array}$} & $\begin{array}{l}\text { Less than } 1 \text { minimum wage } \\
\text { salary }\end{array}$ & - & - & - & - & - & - & - & - \\
\hline & $\begin{array}{l}\text { Between } 1 \text { to } 2 \text { minimum } \\
\text { wage salaries }\end{array}$ & $-9,2 \%$ & 0,317 & $-31,5 \%$ & 0,034 & $10,4 \%$ & 0,495 & $-20,3 \%$ & 0,461 \\
\hline & $\begin{array}{l}\text { More than } 2 \text { minimum wage } \\
\text { salaries }\end{array}$ & $46,4 \%$ & 0,244 & $62,5 \%$ & 0,179 & - & - & - & - \\
\hline \multirow{3}{*}{$\begin{array}{l}\text { Primary } \\
\text { Health Care } \\
\text { Center }\end{array}$} & Canapote & - & - & - & - & - & - & - & - \\
\hline & San Francisco & $17,2 \%$ & 0,034 & - & - & - & - & - & - \\
\hline & Tierra Bomba & $11,9 \%$ & 0,048 & - & - & - & - & - & - \\
\hline \multirow{5}{*}{ Occupation } & Employed & - & - & - & - & - & - & - & - \\
\hline & $\begin{array}{l}\text { Actively looking for } \\
\text { employment }\end{array}$ & $-6,1 \%$ & 0,773 & $-15,9 \%$ & 0,581 & $29,5 \%$ & 0,391 & - & - \\
\hline & Student & $21,3 \%$ & 0,469 & $-24,9 \%$ & 0,646 & $34,0 \%$ & 0,498 & $36,4 \%$ & 0,492 \\
\hline & House wife & $-3,0 \%$ & 0,743 & $20,4 \%$ & 0,253 & $-9,5 \%$ & 0,460 & $-6,5 \%$ & 0,765 \\
\hline & Disabled or retired & $11,8 \%$ & 0,535 & $-1,5 \%$ & 0,959 & $-35,1 \%$ & 0,360 & $53,9 \%$ & 0,122 \\
\hline \multirow{3}{*}{$\begin{array}{l}\text { Time (years) } \\
\text { since } \\
\text { diagnosis of } \\
\text { hypertension }\end{array}$} & $0-5$ years & - & - & - & - & - & - & - & - \\
\hline & $6-10$ years & $-2,9 \%$ & 0,753 & $5,8 \%$ & 0,709 & $2,2 \%$ & 0,880 & $-24,7 \%$ & 0,256 \\
\hline & More than 10 years & $-14,3 \%$ & 0,323 & $-3,4 \%$ & 0,893 & $-34,0 \%$ & 0,092 & $82,6 \%$ & 0,090 \\
\hline \multicolumn{2}{|c|}{ Hypertensive disease knowledge } & $11,5 \%$ & 0,000 & $12,4 \%$ & 0,000 & $10,4 \%$ & 0,000 & $14,1 \%$ & 0,000 \\
\hline
\end{tabular}

Source: Surveys on knowledge and care practices of hypertensive patients in three communities of Localidad 1, city of Cartagena.

Another variable that was statistically significant $(\mathrm{p}<0.05)$ was the Primary Health Care Center (CAP) to which the patient belongs. Our data showed that there are differences among the practices carried out by patients in each of the analyzed communities, since residents in San Francisco exhibited 17.2\% better self-care practices compared to those residing in Canapote, and similarly, residents of Tierra Bomba have $11.9 \%$ better self-care practices than residents of Canapote.

Meanwhile, regarding hypertensive disease knowledge, our data indicate that as it increases or improves, so do self-care practices by $11.5 \%(\mathrm{p}<0.05)$.

\section{Discussion}

In this study, we analyzed the correlation between sociodemographic characteristics and disease knowledge with 
health self-care practices. Our goal was to analyze how responsible were patients in taking care of their disease, and how this could be a determinant factor in the current crisis of the health care system.

Regarding sociodemographic factors, we found that patients were predominantly females $(64.3 \%)$, between 50 59 years of age $(36.2 \%)$, and $34.1 \%$ were over 60 years of age. In total, $47.6 \%$ of respondents had low educational level (elementary), and 37.3\% reported achieving high school level. Regarding socioeconomic level, the majority of participants were classified in the lowest level, which is expected since the majority of the residents in those areas are of low income. Our observations are consistent with those reported in the Garrido study, in which the average age of participating hypertensive patients in Chile was $55.4 \pm 7.7$ years, a $31.5 \%$ had received 8 or less years of education; $23.9 \%$ reported low income ( $<15.59$ USD per person), and the disease affected predominantly females $(33,2 \%$ vs. $28,9 \%$ in males; $p=0.01)$ (Garrido et al., 2013).

Our results suggest that hypertensive individuals have high $(60.5 \%)$ and mediocre $(36.8 \%)$ levels of disease knowledge. Silva and colleagues reported similar findings, in which adequate disease knowledge was found to be predominant $(82.23 \%)$ in a group of hypertensive patients (Silva, Olivera \& Silva, 2014). Likewise, Serafim and colleagues reported high levels of knowledge $(80 \%)$ related to non-medicated interventions such as smoking cessation, weight loss, exercising, lower alcohol intake, as treatments for hypertension (Serafim, Jesus \& Pierin, 2010).

Our study population exhibited mediocre $(73.5 \%)$ or poor $(24.3 \%)$ self-care practices. In agreement with our observations, the study by Leyva, Venegas \& Medel (2011) also reported mediocre self-care practices (25\%-79\%) by hypertensive patients. On the contrary, Cuellar et al reported positive practices related to attending control visits, identifying warning signs, and considering that the information provided by health care professionals is sufficient for them to understand treatment (G. Cuellar, Coneo, Camargo, R. Cuellar, \& Betancourth 2015).

Notably, our data indicate that exercising was a predominantly poor $(62.2 \%)$ or mediocre $(37.3 \%)$ self-care practice. In fact, it obtained the worst rating among all six analyzed dimensions in our study, which is in agreement with the Álvarez study (2014), in which this type of self-care practices were rated as mediocre (83.3\%) or poor (13.3\%). Similarly, Espinosa and colleagues determined that disease self-management in hypertensive patients was mostly mediocre (63\%), followed by poor (34\%), and only 3\% was proper (Espinoza, 2017). Strikingly, in relation to use of tobacco, self-care practices were predominantly mediocre $(67 \%)$ and poor $(31.9 \%)$. This is critical, as it has been previously reported by studies -such as that by Diaz and colleagues (Díaz, Quinteros, Cañate \& Bertón, 2011) - that smoking is one of the factors independently associated with ischemic cardiomyopathy, which acts synergistically with high blood pressure and hypercholesterolemia.

Hypertensive disease knowledge was correlated significantly with self-care practices $(\mathrm{p}<0.05)$. As previously proposed by Da Silva, Oliveira, and Silva (2014), this relationship may be explained by a higher level of disease knowledge leading to stronger commitment to self-care and adherence to treatment, which ultimately implies the incorporation of better self-care practices. Embedded in this relationship is health education, through which lifestyle modifications, adherence to prescribed medical treatment, and prevention of damages caused by uncontrolled hypertension can be achieved. Similarly, Aguado and colleagues showed that a high level of hypertensive disease knowledge was significantly correlated to higher levels of healthy self-care practices $(\mathrm{p}=0.002)$ (Aguado, Arias, Sarmiento, \& Danjoi, 2014).

Throughout this study several approaches were taken into consideration in which active participation of patients in self-care practices in the search of prevention and/or control of their disease for their wellbeing was emphasized. Quiñe reported a statistically significant association $(\mathrm{p}<0.005)$ between disease duration and self-care capabilities, in other words, the disease duration -hypertension and/or diabetes- was of 8 or more years in patients (40\%) that followed good self-care practices (Quiñe, 2017). Moreover, this effort must be in partnership with all of the available patient support systems, which should be guided towards disease prevention and health promotion, as it's main axis. In agreement with the above, the WHO states that prevention and control of high blood pressure require political will from governments and regulatory agencies, and in addition health care professionals, researchers, society, the private sector, families, and affected individuals must contribute as well. Only with this conjoined effort will it be possible to use the available diagnostic tools and treatments to successfully prevent and control hypertension, and thus delay or reduce the incidence of potentially lethal complications of this condition (World Health Organization et al., 2013).

Finally, the lack of patient responsibility towards their own disease was evidenced in our study, since even though patients exhibited high levels of disease knowledge their self-care practices were rated as mediocre or poor. This unreasonable context, in which patients are aware but indifferent to their disease, synthetizes the expression the absurd consciousness of those lying in a health care system about to collapse, and is without a doubt an 
underestimated -close to being ignored- determining factor in the current crisis of the health care system. Comparable results by Achury et al. (2012), showed that $81.22 \%(n=199)$ and $8.16 \%(n=20)$ of hypertensive patients showed mediocre and low self-care capabilities, respectively. Thus, the authors propose that in order to achieve patient commitment and participation it is necessary to implement permanent self-care practices that facilitate self-knowledge, empower patients, and develop health care decision-making capabilities.

\section{Conclusion}

Patient behavior constitutes a determinant factor in the health care system crisis, since although hypertensive patients possess good disease knowledge, they do not put it into practice. In other words, while patients are aware that they need to modify their lifestyle in order to avoid complications, they choose not to do so, and instead continue with unhealthy practices such as leading a sedentary lifestyle, unhealthy diet, poor stress management, use of tobacco, and alcohol consumption. Altogether, this constitutes an absurd attitude taking into account that it's related to their wellbeing, and it turns into an attack on a health care system that is about to collapse. Therefore, any implemented strategy will always be at disadvantage unless patient behavior is modified from an early age by teaching proper self-care practices for health maintenance. It should be noted that an important behavioral aspect is consciousness, which captures only that what it considers truly important and attracts our attention. Therefore, creating a culture of adequate self-care should be implemented in early life, that is, from primary (home) and secondary (school) socialization. It would be interesting to also include management of protective factors, and frequent complications of poor health habits in the curriculum, which together with support of health care personnel -especially nursing staff- that has the disciplinary competencies to provide tools to improve lifestyle and to create healthy environments.

Clearly, the current way of thinking needs to change, and the time has come to commit to primary health care, to create environments for health promotion and disease prevention. Instead of waiting for each individual to change, this must be a joint and structured effort by all involved parties aiming to make health prevail as a fundamental social right.

Finally, our results show that in a system that is currently flawed, the only thing that remains is collapse. Therefore it is time to make categorical decisions, where patients that are taking responsibility for their disease are prioritized, and those who are not should be analyzed and categorized according to their health situation in such a way that the system is not affected. In this order of ideas, patient care should require patients to commit to complying with recommendations provided by health care personnel, and furthermore, renewed primary health care strategies should be aimed at a family oriented focus on health promotion and disease prevention as the most cost-effective tool to achieve an integral approach.

\section{Competing Interests Statement}

The authors stated that there was no conflict of interests during this investigation. The study did not have personal, financial and political links with the entities or individuals surveyed.

\section{References}

Achury Beltrán, L. F., Achury Saldaña, D. M., Rodríguez Colmenares, S. M., Sepúlveda Carrillo, G. J., Padilla Velasco, M. P., Lauro Umaña, Y. M., ... \& Camargo Becerra, L. E. (2012). Capacidad de agencia de autocuidado en el paciente con hipertensión arterial en una institución de segundo nivel. Investigación en Enfermeria: Imagen y Desarrollo, 14(2). Retrieved from http://www.redalyc.org/html/1452/145226758005/

Aguado, E., Arias, M., Sarmiento, G., \& Danjoy, D. (2014). Asociación entre conocimiento y autocuidado sobre hipertensión arterial en pacientes hipertensos, consultorio de cardiología, Hospital Nacional. Rev. enferm. herediana, 7(2), 132-139. Retrieved from https://faenf.cayetano.edu.pe/images/pdf/Revistas/2014/julio/Especial\%204-7-2.pdf

Ahola, J. (2015). The Evolving Idea of Social Responsibility in Bioethics: A Welcome Trend. Cambridge Quarterly of Healthcare Ethics, 24(2), 204-213. https://doi.org/10.1017/S0963180114000516

Álvarez, E. (2015). Nivel de conocimientos de los adultos mayores sobre prevención de hipertensión arterial en un centro de salud, Lima, 2014. Lima: Universidad Nacional Mayor De San Marcos. Retrieved from $\mathrm{http}: / /$ repositorio.autonomadeica.edu.pe/handle/autonomadeica/112

Arias, F. (2012). El Proyecto de Investigación. Introducción a la metodología científica. (5). Venezuela, Caracas. Episteme C.A.

Arrioja, G. (2011). Estilo de vida en el paciente con hipertensión arterial. Universidad Autónoma de Nuevo León. Tesis doctoral. Retrieved from http://eprints.uanl.mx/6182/1/1080091870.PDF 
Blanco, Y. (2017). Nivel de autocuidado y su relación con las complicaciones cardiovasculares del adulto hipertenso que asiste al consultorio de cardiología del policlínico municipal de Jesús María-UBAP-Es Salud-enero. Retrieved from http://renati.sunedu.gob.pe/handle/sunedu/147300

Bloom, D. E., Cafiero, E., Jané-Llopis, E., Abrahams-Gessel, S., Bloom, L. R., Fathima, S., ... \& O'Farrell, D. (2012). The global economic burden of noncommunicable diseases (No. 8712). Program on the Global Demography of Aging. Retrieved from https://ideas.repec.org/p/gdm/wpaper/8712.html

Cabeza, E., March, S., Cabezas, C., \& Segura, A. (2016). Promoción de la salud en atención primaria: si Hipócrates levantara la cabeza. Gaceta Sanitaria, 30, 81-86. https://doi.org/10.1016/j.gaceta.2016.05.012

Catford, J., \& Nutbeam, D. (1984). Towards a definition of health education and health promotion. Health Educ J., 43(2), 38-39. Retrieved from https://doi.org/10.1177/001789698404300203

Chattopdhyay, S. (2013). Corruption in healthcare and medicine: Why should physicians and bioethicists care and what should they do. The Indian Journal of Medical Ethics, 10(3), 153-9. https://doi.org/10.20529/IJME.2013.049

Chávez, R., Villafuerte, G., \& Legua, R. (2008). Tratamiento y costos farmacológicos de la hipertensión arterial no complicada en un Hospital Regional. Rev. Peruana Cardiol, 34(3), 181-190. Retrieved from http://200.62.146.19/BVRevistas/cardiologia/v34_n3/pdf/a06v34n3.pdf

Coronoel, G. D., Quinteros, C., Oliva, C. C., Bertón, P., De Los Santos, M., Loyola, N., ... \& Vigil, M. Prevalencia de hipertensión arterial y factores biopsicosociales asociados, en población adulta de Villa Allende, Córdoba. Revista de Salud Pública, 15(1), 49-64. http://dx.doi.org/10.31052/1853.1180.v15.n1.7011

Correia, T., Dussault, G., \& Pontes, C. (2015). The impact of the financial crisis on human resources for health policies in three southern-Europe countries. Health Policy, 119(12), 1600-1605. https://doi.org/10.1016/j.healthpol.2015.08.009

Cuéllar, G., Coneo, O., Camargo, S., Cuellar, R., \& Betancourth, C. (2015). Conocimientos, actitudes y prácticas del paciente hipertenso de la ciudad de Florencia, Colombia. RFS, 7(1), 32-38. https://doi.org/10.25054/rfs.v7i1.177

Da Silva, M., Oliveira, A., \& Silva, S. (2014). Conhecimento sobre hipertensão arterial e fatores associados à não adesão à farmacoterapia. Rev Latino-Am. Enfermagem, 22(3), 491-8. https://doi.org/10.1590/0104-1169.3447.2442

Diccionario de la lengua espa-ola. (1992). Edición, del tricentenario. Madrid: Real Academia Espa-ola. 1992. Retrieved from http://www.rae.es/obras-academicas/diccionarios/diccionario-de-la-lengua-espanola

Espinoza, L. (2017). Automanejo en adultos con hipertensión arterial en el consultorio externo del hospital Carlos Lanfranco la Hoz Puente Piedra-Lima-Perú. Retrieved from http://repositorio.ucv.edu.pe/handle/UCV/3755

Garrido, J., Chacón, J., Sandoval, D., Muñoz, R., López, N., Oyarzún, E., ... \& Romero, T. (2013). Control del Hipertenso, un desafío no resuelto: Avances logrados en Chile mediante el Programa de Salud Cardiovascular. Revista chilena de cardiología, 32(2), 85-96. https://doi.org/10.4067/S0718-85602013000200001

Gómez, L. (2011). Las enfermedades cardiovasculares: un problema de salud pública y un reto global. Biomédica, 31(4), 469-73. https://doi.org/10.7705/biomedica.v31i4.626

González, I., Rodríguez, G., Castellano, T., \& Pérez, M. (2014). Caracterización de hipertensión arterial en adultos mayores. El Polígono. Policlínico Jimmy Hirzel. Multimed, 19(4). Retrieved from http://www.medigraphic.com/cgi-bin/new/resumen.cgi?IDARTICULO=60542

Guibert, W. (2002). La promoción de salud ante el suicidio. Revista Cubana de Medicina General Integral, 18(1), 3-45. Retrieved from http://scielo.sld.cu/scielo.php?pid=S0864-21252002000100005\&script=sci_arttext\&tlng=pt

Hadad, J., \& Valdés, E. (2010). La protección social en salud como enfrentamiento a una crisis económica. Revista Cubana de Salud Pública, 36, 235-248. https://doi.org/10.1590/S0864-34662010000300008

Ifanti, A., Argyriou, A., Kalofonou, F., \& Kalofonos, H. (2013). Financial crisis and austerity measures in Greece: their impact on health promotion policies and public health care. Health policy, 113(1-2), 8-12. https://doi.org/10.1016/j.healthpol.2013.05.017

Leyva, R., Venegas, E., \& Medel, G. (2011). La capacidad de autocuidado en el control del paciente hipertenso. Revista de investigación Clínica, 63(4), 376-381. Retrieved from 
http://www.medigraphic.com/cgi-bin/new/resumen.cgi?IDARTICULO $=41513$

Marin, M. J., Fábregues, G., Rodríguez, P. D., Díaz, M., Paez, O., Alfie, J., ... \& González, M. (2012). Registro Nacional de Hipertensión Arterial: Conocimiento, tratamiento y control de la hipertensión arterial. Estudio RENATA. Revista argentina de cardiología, 80(2), 121-129. Retrieved from http://www.scielo.org.ar/scielo.php?script=sci_arttext\&pid=S1850-37482012000200005

Márquez, S., Villegas R., Soler, G., \& Martínez, F. (2014). Promoción de la salud y prevención en tiempos de crisis: el rol del sector sanitario. Informe SESPAS. Gaceta Sanitaria, 28, 116-123. https://doi.org/10.1016/j.gaceta.2014.01.012

Mazón, P. (2012). Riesgo cardiovascular en el siglo XXI. Cómo detectarlo en prevención primaria. Cómo controlarlo en prevención secundaria. Revista Espa-ola de Cardiología, 65, 3-9. https://doi.org/10.1016/j.recesp.2012.07.004

Ministerio de Salud de la República de Colombia. Resolución 8430 de 1993. (1993). Por la cual se establecen las normas científicas, técnicas y administrativas para la investigación en salud. Bogotá: Ministerio de Salud. Retrieved from https://www.minsalud.gov.co/sites/rid/Lists/BibliotecaDigital/RIDE/DE/DIJ/ RESOLUCION-8430-DE-1993.PDF

Mundial, Banco. Poverty and Shared Prosperity. (2016). Taking on Inequality. Washington DC: Banco Mundial doi, $10, \quad 978 . \quad$ Retrieved $\quad$ from https://openknowledge.worldbank.org/bitstream/handle/10986/25078/9781464809583.pdf

OMS. (2015) Salud y derechos humanos. Nota descriptiva $\mathrm{N}^{\circ} 323$. Retrieved from http://www.who.int/mediacentre/factsheets/fs323/es/

Ongaro, E., Ferre, F., \& Fattore, G. (2015). The fiscal crisis in the health sector: Patterns of cutback management across Europe. Health Policy, 119(7), 954-963. https://doi.org/10.1016/j.healthpol.2015.04.008

Qui-e, A. (2017). Factores sociodemográficos y capacidad de autocuidado del paciente adulto con hipertensión y diabetes. Retrieved from http://dspace.unitru.edu.pe/handle/UNITRU/8625

Reventos, D. E., Wong, T. H., Ugena, J. A., Barroso, P. A., Pérez, R. C., Llorach, E. G., ... \& Baró, M. S. (2013). Validación de un cuestionario de conocimientos sobre la hipertensión. Hipertensión y riesgo vascular, 30(4), 127-134. https://doi.org/10.1016/j.hipert.2013.05.003

Roca, A. (2017). Reflexiones sobre la corrupción y su impacto sobre salud. Medicina, 39(1), 5-7. Retrieved from http://revistamedicina.net/ojsanm/index.php/Medicina/article/view/116-1

Ruiz, Á. (2011). Retos y desafíos de la seguridad social latinoamericana: entre la realidad y la utopía. Revista Latinoamericana de Derecho Social, (12). Retrieved from http://www.redalyc.org/pdf/4296/429640267004.pdf

Saez, M., \& Barceló, A. (2012). Coste de la hipertensión arterial en Espa-a. Hipertensión y riesgo vascular, 29(4), 145-151. Retrieved from https://doi.org/10.1016/j.hipert.2012.07.003

Semplicl, S. (2011). The importance of 'social responsibility'in the promotion of health. Medicine, health care and philosophy, 14(4), 355-363. https://doi.org/10.1007/s11019-011-9329-9

Serafim, T., Jesus, E., \& Pierin, A. (2010). Influencia del conocimiento sobre el estilo de vida saludable en el control de la hipertensión. Acta Paul Enferm, 23(5), 658-664. https://doi.org/10.1590/S0103-21002010000500012

Silva, M., Oliveira, A., \& Silva, S. (2014). Conocimiento sobre hipertensión arterial y factores asociados a la no adhesión a la farmacoterapia. Revista Latino-Americana de Enfermagem, 22(3), 491-498. http://dx.doi.org/10.4067/S0718-85602013000200001

Solano, F., Tamay, P., Quizhpe, G., \& Villamar, Z. (2017). Factores de riesgo asociados a diabetes e hipertensión. In Conference Proceedings l(1). Retrieved http://investigacion.utmachala.edu.ec/proceedings/index.php/utmach/article/view/24

Sørensen, K., \& Brand, H. (2011). Health literacy-A strategic asset for corporate social responsibility in Europe. Journal of health communication, 16(3), 322-327. https://doi.org/10.1080/10810730.2011.606072

Urbanos, R. (2010). La salud en todas las políticas. Tiempo de crisis, ¿tiempo de oportunidades? Informe SESPAS. Gaceta Sanitaria, 24, 7-11. https://doi.org/10.1016/j.gaceta.2010.05.003

World Health Organization [WHO]. (2013). Información general sobre la hipertensión en el mundo. Geneva: 
World Health Organization. $\quad$ Retrieved from http://apps.who.int/iris/bitstream/handle/10665/87679/who_dco_whd_2013.2_spa.pdf;jsessionid=E52346E 672305D480837F5DDE3F838E1? sequence=1

Yepes, F., \& Sánchez, L. (2008). La reforma del sector de la salud en Colombia: un modelo de competencia regulada?. Revista Panamericana de Salud Pública, 8, 34-35. Retrieve from https:/www.scielosp.org/scielo.php?pid=S1020-49892000000700022\&script=sci_arttext\&tlng=en

\section{Copyrights}

Copyright for this article is retained by the author(s), with first publication rights granted to the journal.

This is an open-access article distributed under the terms and conditions of the Creative Commons Attribution license (http://creativecommons.org/licenses/by/4.0/). 